\title{
Primer cutan diffúz nagy B-sejtes lymphoma, leg type
}

\section{Primary cutaneous diffuse large B-cell lymphoma, leg type}

\author{
ZUBONYAI CECÍLIA DR. ${ }^{1}$, BATTYÁNI ZITA DR. ${ }^{1}$, KOLLÁR BALÁZS DR. ${ }^{2}$, \\ EGYED MIKLÓS DR. ${ }^{2}$
}

\begin{abstract}
Somogy Megyei Kaposi Mór Oktató Kórház Bőrgyógyászati Osztály², Somogy Megyei Kaposi Mór Oktató Kórház Belgyógyászati Osztály Haematológiai Részleg², Kaposvár, Magyarország
\end{abstract}

\section{ÖSSZEFOGLALÁS}

A szerzốk 79 éves nöbeteg esetét mutatják be, akinek felvételekor a jobb lábon és a lábszár alsó felén szabálytalanul vörös plakkok és tömött csomók helyezkedtek el. A börbiopszia szövettani vizsgálata a reticularis dermist és a subcutist infiltráló, primer cutan diffúz nagy B-sejtes lymphoma, leg type formát igazolt. A laboratóriumi és a képalkotó vizsgálatok belszervi manifesztációra nem utaltak.

A beteg általános állapota miatt csökkentett dózisban alkalmazott 6 ciklus $R$-CHOP kezelés hatására a börtünetek átmenetileg regrediáltak. A késóbbi progresszió során az $R$-CHOP terápiára észlelt rezisztencia miatt a kombinációt etopoziddal egészítették ki, melyre csontvelö aplasia alakult ki, bár a lymphoma átmenetileg, rövid időre regrediált. Az ismételt progresszió során rituximab-etopozid terápiával és sugárkezeléssel próbálkoztak, de a beteg állapotának gyors hanyatlása miatt a kezelést leállították, s a beteg hamarosan sepsisben meghalt. Szerző́k az eset kapcsán röviden összefoglalják az alsó végtagi típusú, primer cutan diffúz nagy B-sejtes lymphomával kapcsolatos jelenlegi ismereteket, kezelési lehetőségeket.

\section{Kulcsszavak: primer cutan B-sejtes lymphoma - R-CHOP}

\section{SUMMARY}

The case of a 79 years old female patients is presented, who was admitted with irregular red plaques and solid nodules on the lateral aspect of the right lower extremity. Histological examination of the skin biopsy showed primary cutaneous diffuse large B cell lymphoma, leg type with reticular dermis and subcutaneous infiltration. Laboratory and imaging studies did not show internal organ manifestations. Due to the patient's general condition 6 cycles of reduced dose of $\mathrm{R}$-CHOP treatment was used and the skin symptoms temporarily regressed. In the subsequent progression due to the developed resistance to the R-CHOP therapy etoposide was added in combination therapy, which developed bone marrow aplasia, while the lymphoma temporarily and briefly regressed. During the subsequent progression rituximabetoposide and radiation treatment was attempted, but due to the patient's rapid decline the treatment was interrupted, and the patient died shortly after that in sepsis. Based on this case the authors briefly summarized the recent knowledge and treatment options of the primary cutaneous diffuse large B-cell lymphoma, leg type.

\section{Key words: \\ Primary cutaneous B cell lymphoma - R-CHOP}

A primer cutan diffúz nagy B-sejtes lymphoma ritka betegség, melyen belül a ritka, rossz prognózisú, leg type (lábszári típus) külön entitást képvisel (1. táblázat). Az idôs kor betegsége, nôknél gyakoribb. Általában multiplex bőrtünetek jellemzik. Kezelésében elsődlegesen az immuno-kemoterápia választandó, csak soliter tünet esetén javasolt a sebészi excisio vagy a radioterápia. A terápia tervezésekor figyelembe kell venni a beteg általános állapotát és kísérô betegségeit. Relapsus hajlama és a betegek általában idős kora miatt prognózisa rossz.

\section{Esetismertetés}

A 79 éves nóbeteg anamnesisében az 1970-es évek óta hypertonia, csípó-, térdízületi és gerinc panaszok miatti kezelés, 1988-ban méhtest rák miatt uterus exstirpatio kétoldali adnexectomiával, majd sugárterápia, 2006-ban perforáló duodenális ulcus miatt mútét (sutura) szerepel. Gyógyszerei: Tritace HCT (ramipril, hydrochlorothiazide) 5/25, Amlipin (amlodipine), Lokren (betaxolol), Omeprazol (omeprazole), Dormicum (midazolam), Algopyrin (metamizol).

2006. novemberben 2 hónapja kezdődő, fájdalmat, viszketést, időnként nedvezést okozó bôrtünetei miatt került felvételre a Somogy 


\begin{tabular}{|c|}
\hline $\begin{array}{r}\text { Cutan T-sejtes és NK-sejtes lymphomák } \\
\end{array}$ \\
\hline Mycosis fungoides \\
\hline $\begin{array}{l}\text { MF variánsok és altípusok } \\
\text { - Folliculotrop MF } \\
\text { - Pagetoid reticulosis } \\
\text { - Granulomatous slack skin }\end{array}$ \\
\hline Sézary-syndroma \\
\hline Felnốttkori T-sejt leukaemia/lymphoma \\
\hline $\begin{array}{l}\text { Primer cutan CD30+ lymphoproliferativ betegségek } \\
\text { - Primer cutan anaplasticus nagy sejtes lymphoma } \\
\text { - Lymphomatoid papulosis }\end{array}$ \\
\hline Subcutan panniculitis-like T-cell lymphoma \\
\hline Extranodális NK/T-sejtes lymphoma, nasal type \\
\hline $\begin{array}{l}\text { Primer cutan peripheriás T-sejtes lymphoma, nem meghatározott } \\
\text { - Primer cutan agresszív epidermotrop CD8+ T-sejtes lymphoma (provisional) } \\
\text { - Cutan } \gamma / \delta \text { T-sejtes lymphoma (provisional) } \\
\text { - Primer cutan CD4+ kis/közepes pleomorph T-sejtes lymphoma (provisional) }\end{array}$ \\
\hline Cutan B-sejtes lymphomák \\
\hline Primer cutan marginális zóna B-sejtes lymphoma (PCMZL) \\
\hline Primer cutan folliculus centrum lymphoma (PCFCL) \\
\hline Primer cutan diffúz nagy B-sejtes lymphoma, leg type (PCDLBCL-LT) \\
\hline $\begin{array}{l}\text { Primer cutan diffúz nagy B-sejtes lymphoma, egyéb } \\
\text { - Intravascularis nagy B-sejtes lymphoma }\end{array}$ \\
\hline Precursor hematologic neoplasm \\
\hline CD4+/CD56+ hematodermic neoplasm (blastos NK-sejtes lymphoma) \\
\hline
\end{tabular}

\section{1. táblázat}

Primer cutan lympomák WHO-EORTC beosztása (18)

Laboratóriumi vizsgálattal észlelt eltérések: vvt 4,00 T/1 (normál 4,1-5,1 $\mathrm{T} / \mathrm{l}$ ), We $35 \mathrm{~mm} / \mathrm{h}$ (normál $5-30 \mathrm{~mm} / \mathrm{h}$ ), serum kreatinin 151 umol/l (normál 4490 umol/l).

A hgb, fvs, thc, minőségi vérkép, CN, LDH, GOT, GPT, GGT, alk. foszf., vércukor normál tartományban volt. Vizelet vizsgálat során pyuriát észleltünk, a bakteriológiai tenyésztés Klebsiella pneumoniae fertôzést igazolt, mely célzott Sumetrolim kezelésre meggyógyult. Széklet benzidin 3x neg.

Mellkas röntgen során mindkét irányba minimálisan megnagyobbodott szívet, az aortagomb falában meszesedést észleltek, egyéb kóros eltérés nem ábrázolódott.

Hasi UH: Mindkét vesén chronicus parenchyma laesio. Arteriosclerosis aortae abdominis. Részleges thromboticus jobb oldali art. iliaca communis, körülírt aneurysmaszerú tágulattal, az aktív lumen $7 \mathrm{~mm}$. Hernia parietis abdominis. Megnagyobbodott nyirokcsomó sem a hasban, sem az inguinalis régióban nem ábrázolódott.

Differenciáldiagnosztikai szempontból cutan lymphoma, histiocytosis, sarcomák és sarcoidosis lehetôsége merült fel, ezért próbaexcisiot végeztünk az egyik csomóból.

A szövettani vizsgálat HE festett metszetein ép epidermis alatt a dermist és a subcutist tömeges, éretlen, nagyrészt mononuclearis sejtekből álló daganatszövet infiltrálta (2. ábra, 3. áb$r a$ ). Immunhisztokémiai vizsgálattal szelektív CD20 membrán pozitivitást, részleges MUM-1 pozitivitást mutat-

Megyei Kaposi Mór Oktató Kórház Bőrgyógyászati Osztályára. Fogyást, éjszakai izzadást nem panaszolt. Láztalan volt. Felvételkor testmagassága $148 \mathrm{~cm}$, testtömege $50 \mathrm{~kg}$.

Felvételkor a jobb külboka előtti területen 0,5-1,5 cm-es, lividvörös, tömött csomókból álló, gyưrúszerú plakk, a lábszár alsó harmadában néhány, hasonló, helyenként erodált csomó, a lábhát laterális részén elmosódott határú, lividvörös, enyhén beszűrt plakk helyezkedett el (1.ábra). Kóros nyirokcsomó, lép, máj nem volt tapintható.

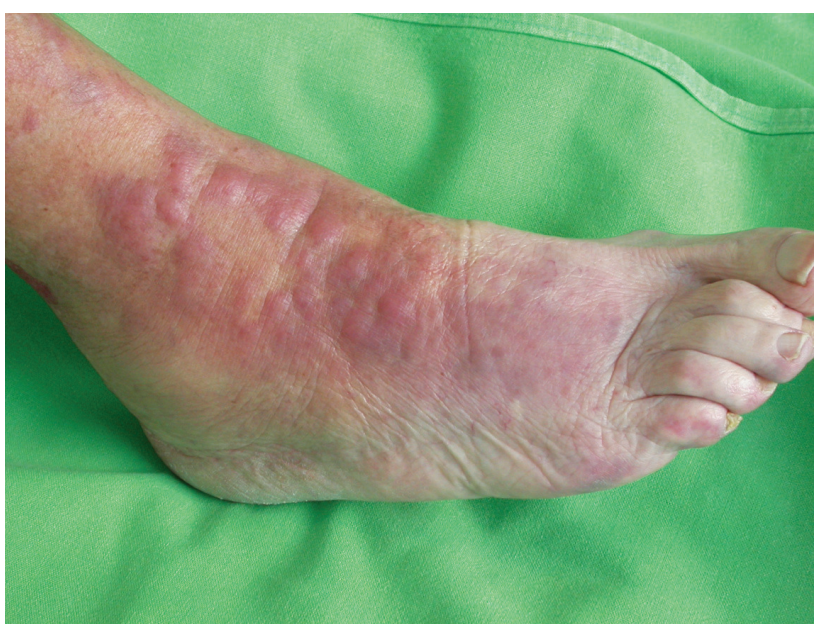

1. ábra

Lividvörös csomók a jobb külboka előtti területen tak (4. ábra). A CD3, CD30, CD10 és BCL-6 reakciók negatívak voltak.

A vizsgálatok alapján a primer cutan diffúz nagy B-sejtes lymphoma, leg type diagnózist állítottuk fel. A beteget kórházunk hematológiai részlegére irányítottuk.

A hematológiai osztályon a beteg általános állapota miatt noninvazív vizsgálatok (nyak, mellkas, has CT) történtek, melyek disszeminációra nem utaltak. Laboratóriumi vizsgálata során mérsékelten emelkedett volt: We $39 \mathrm{~mm} / \mathrm{h}$, serum kreatinin $196 \mu \mathrm{mol} / \mathrm{l}$, CRP

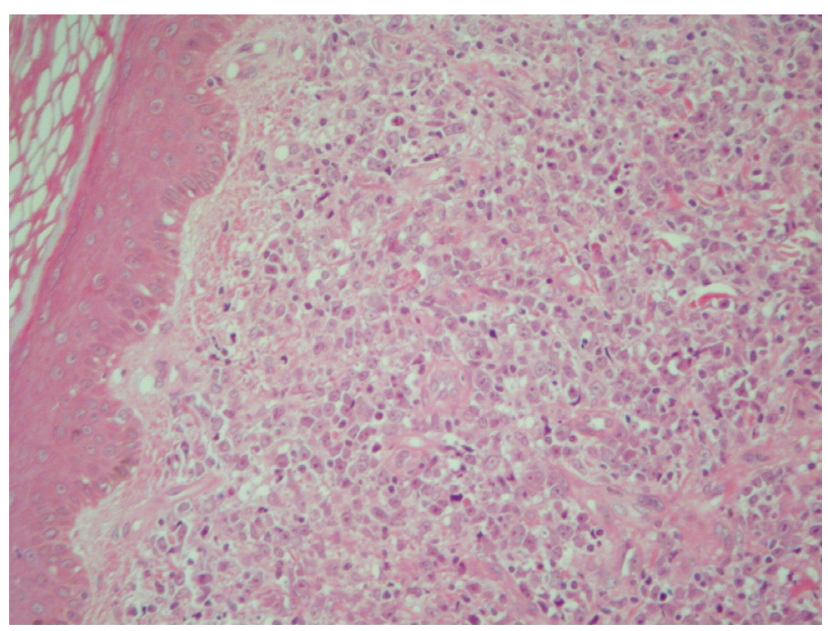

2. ábra

A dermist és a subcutist diffúzan infiltráló tumorsejtek

(HE 10x) 


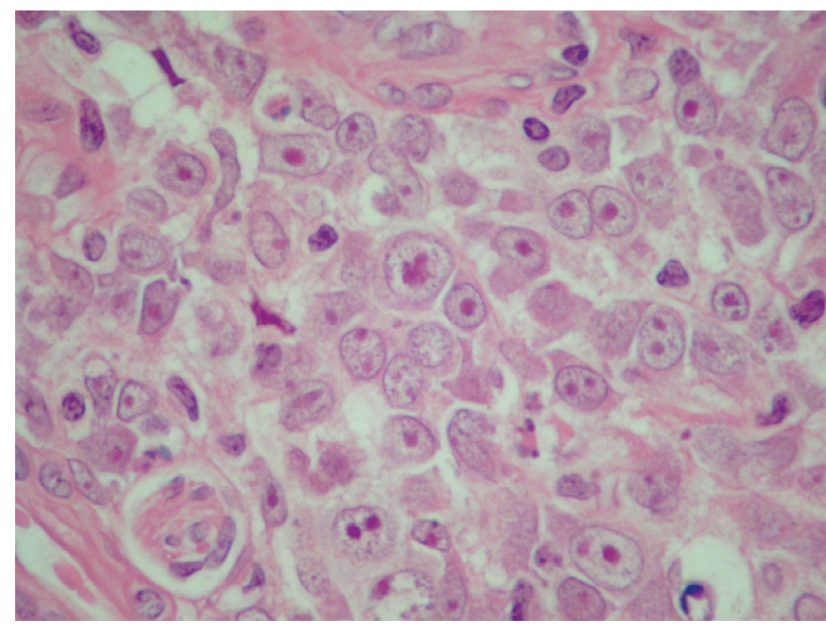

3. ábra

Nagy méretú, polymorph tumorsejtek (HE 40x)

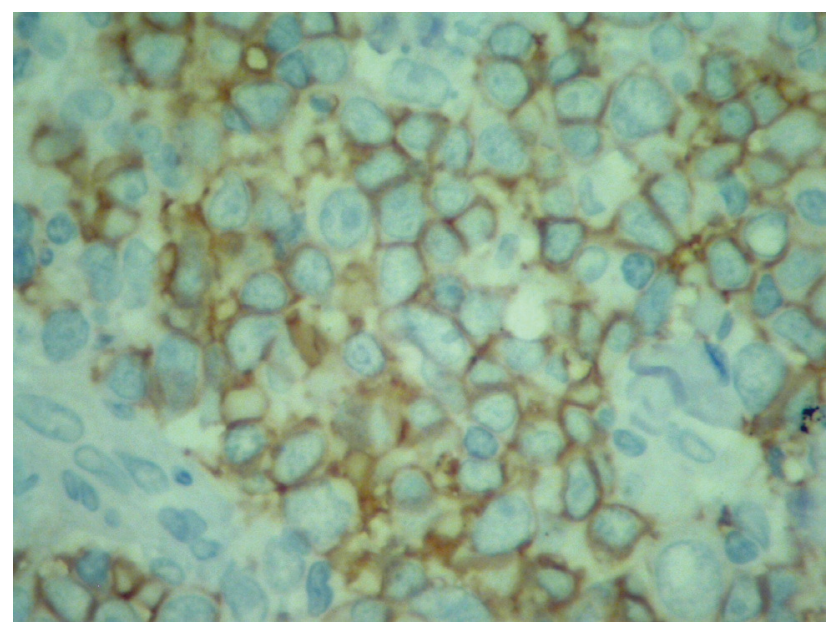

4. ábra

A tumor sejtek CD20 membrán pozitivitása (HE 40x)

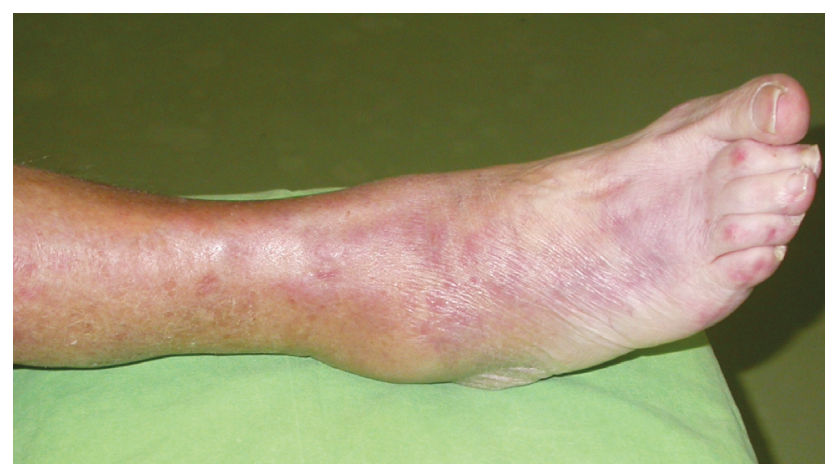

5. ábra

Nagyfokú tumor regresszió már 2 ciklus R-CHOP után

6,65 mg/l (normál 0,00-6,60 mg/l), LDH 538 U/l (normál 240-530 U/l), húgysav $413 \mu \mathrm{mol} / \mathrm{l}$ (normál 150-360 $\mu \mathrm{mol} / \mathrm{l})$. A jelenleg érvényes TNM stádium beosztás alapján (2. táblázat) a lymphoma stádium T2cNOM0. Tekintettel a beteg korára, ECOG 2-es állapotára, rituximabbal kombináltan csökkentett dózisú CHOP (ciklofoszfamid, epirubicin, vincristin, methylprednisolon) kezelést kezdtek. A beteg 21 naponként 6 ciklus R-CHOP kúrát kapott 2006.12.12-tól 2007.03.27-ig. Klinikailag komplett remisszió alakult ki (5. ábra). Mellékhatásként enyhe hányinger és anaemia jelentkezett.

\begin{tabular}{|c|c|}
\hline \multicolumn{2}{|l|}{$\mathbf{T}$} \\
\hline & $\begin{array}{l}\text { soliter bőrtünet } \\
\text { T1a: }<5 \mathrm{~cm} \\
\text { T1b: }>5 \mathrm{~cm}\end{array}$ \\
\hline & $\begin{array}{l}\text { regionális bórtünet ( } 1 \text { vagy } 2 \text { szomszédos régió) } \\
\text { T2a: az összes tünet }<15 \mathrm{~cm} \\
\text { T2b: } 15-30 \mathrm{~cm} \\
\text { T2c: }>30 \mathrm{~cm}\end{array}$ \\
\hline T3: & $\begin{array}{l}\text { generalizált bórtünet } \\
\text { T3a: multiplex tünet } 2 \text {, nem szomszédos bôr } \\
\text { régióban } \\
\text { T3b: multiplex tünet } 3 \text { vagy több bôr régióban }\end{array}$ \\
\hline \multicolumn{2}{|l|}{$\mathbf{N}$} \\
\hline & $\begin{array}{l}\text { N0: nincs klinikai vagy szövettani vizsgálattal } \\
\text { igazolt nyirokcsomó eltérés }\end{array}$ \\
\hline & $\begin{array}{l}\text { N1: egy perifériás nyirokcsomó régió érintett } \\
\text { (a bőrtünetet drenáló nyirokrégió) }\end{array}$ \\
\hline & $\begin{array}{l}\text { N2: két vagy több, vagy bármely, nem drenáló } \\
\text { nyirokrégió érintett }\end{array}$ \\
\hline & N3: centrális nyirokcsomó érintettség \\
\hline \multicolumn{2}{|r|}{ 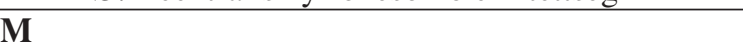 } \\
\hline & M0: nincs extracutan érintettség \\
\hline & M1: extracutan érintettség \\
\hline
\end{tabular}

\section{2. táblázat}

A nem mycosis fungoides és nem Sézary-syndroma típusú primer cutan lymphomák TNM stádium beosztása (8)

2007. májusban, 7 hét elteltével lokális recidívát észleltek szisztémás terjedésre utaló tünetek nélkül. Ekkor a laboratóriumi eltérések:

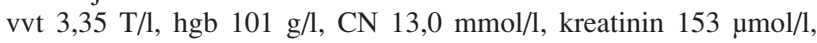
LDH 817 U/l, normál fvs, thc, májenzimek, ionok. Ismét R-CHOP kezelést indítottak, tekintettel a korábbi eredményességre és a kevés mellékhatásra.

4 ciklus után lokális progresszió, általános tünetek (9 kg-os fogyás, éjjeli izzadás) miatt a kezelést 2007. augusztusban etopoziddal (R-CHOEP) egészítették ki, melyre átmeneti regresszió jelentkezett súlyos pancytopeniával (vvt 2,43 T/l, hgb $73 \mathrm{~g} / 1$, fvs $0,1 \mathrm{G} / \mathrm{l}$, thc 41 $\mathrm{G} / \mathrm{l}$ ), lázzal kísérve. A csontvelő aplasia, lázas állapot $4 \mathrm{E}$ vörösvértest koncentrátum, 7 napon át $30 \mathrm{ME} /$ nap G-CSF Neupogen (filgrastim) és parenterális széles spektrumú antibiotikum (ceftriaxon) hatására rendeződött.

4 hét múlva ciklofoszfamid nélkül került sor a kemoterápia ismétlésére. Bár ezúttal súlyos mellékhatás nem volt, de a bő́rtünetek progrediáltak.

Laboratóriumi eredményében fokozódó anaemia és LDH emelkedés jelentkezett: We 54 mm/h, vvt 3,41 T/l, hgb 97 g/l, LDH 1295 U/l, serum kreatinin 121 umol/l, összfehérje 58 g/l (normál 64-85 $\mathrm{g} / \mathrm{l})$, normál fvs, thc, $\mathrm{CN}$, húgysav, glukóz, májenzimek, vizelet.

2007. október elején a jobb alsó végtag MR a lábszár proximális negyede magasságától a felsố ugróízület magasságáig csaknem körkörösen, helyenként konfluáló jelleggel a cutisban, a subcutan zsírszövetben és az izomzatban is számtalan, 10-35 mm-es, közepes jelintenzitású szolid gócot mutatott. $24 \mathrm{~mm}$-es szolid képlet látszott bal oldalon a musculus soleus középső harmadában is. A mellkas, has CT-n kóros nyirokcsomó, splenomegalia nem ábrázolódott.

A lokális progresszió miatt, mivel a beteg kora, általános állapota az agresszív kemoterápiát ellenjavallta, radioterápiára készülttek CT alapú, 3 dimenziós tervezés alapján 2 mezóből, 6 frakcióban, 6MVvel, 10,8 Gy összdózisban. Rituximab, etopozid, methylprednisolon kezelés után 7 nappal indították a sugárkezelést, de 4 alkalom után a kialakuló láz, csontvelő aplasia (fvs 0,7 G/l, vvt 2,42 T/l, hgb 70 g/l, thc 76 G/l) és Staphylococcus aureus sepsis miatt felfüggesztették. Szupportív terápia hatására (vörösvértest koncentrátum, G-CSF, antibiotikum) az aplasia, sepsis megszúnt, a bőrtünetek beszúrtsége 


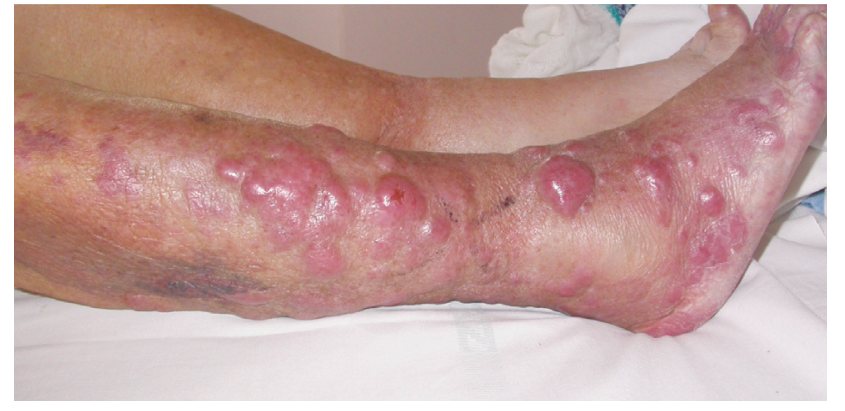

6. ábra

2007. október elején látható tumor progresszió

csökkent, a beteg rossz általános állapota miatt azonban a sugárkezelést nem folytatták (6. ábra).

Kb. 2 hét múlva ismételt láz, gyengeség, a jobb kar fájdalmas duzzanatával kísért bullosus bőrgyulladása, lymphoma progresszió miatt került felvételre.

Kóros laborértékei: normál fvs (9,3 G/l) mellett neutrofilia 8,9 G/l, vvt 2,55 T/l, hgb 76 g/l, serum összfehérje 43 g/l, albumin 23 g/l, CRP 264,94 mg/l, CN 15,3 mmol/l, kreatinin 167 umol/l, LDH 525 U/l. A jobb kar Doppler UH vizsgálat a thrombosist kizárta, lymphoedemát igazolt. Széles spektrumú parenterális antibiotikum (Maxipime: cefepime), alacsony molsúlyú heparin (Clexane: enoxaparin-nátrium) adása, a folyadék és ion egyensúly fenntartása ellenére a beteg állapota hanyatlott, felvétele után 2 héttel exitált (7. áb$r a)$. Boncolás a család kérésére nem történt.

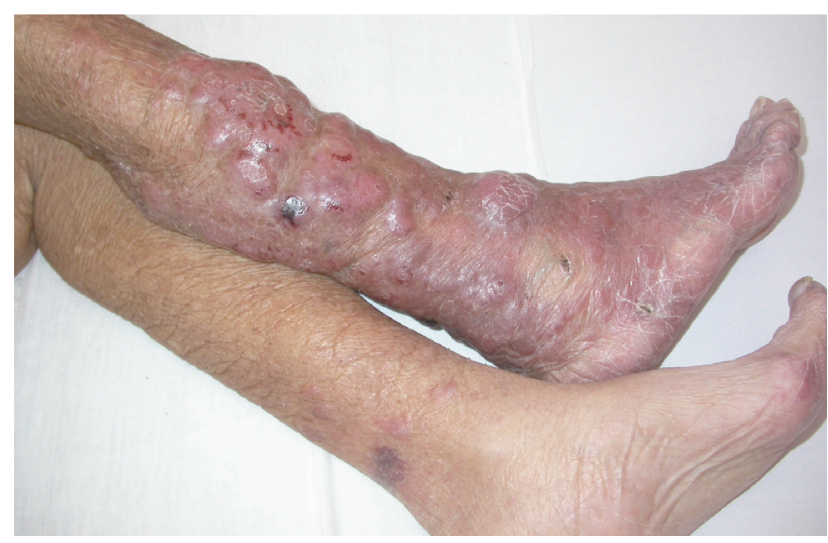

7. ábra

2007. október végén látható további progresszió

\section{Megbeszélés}

Primer cutan lymphomáról akkor beszélhetünk, ha a diagnózis felállításakor más szervben, szövetben a malignus sejtek nem mutathatók ki. A primer cutan B-sejtes lymphomák a nodális formáknál sokkal ritkábbak, lefolyásuk, prognózisuk, kezelésük is eltérhet attól (6).

A primer cutan lymphomás betegekról gyúlő klinikai adatok, a bôvülő immunológiai és genetikai ismeretek, az újabb terápiákkal szerzett tapasztalatok alapján készült a jelenleg érvényes klasszifikáció, melynek feladata ezen ritka betegségekben a diagnózis felállításának és a kezelésnek a segítése (18). A legújabb, 2008-as haemopoieticus és lymphoid tumor klasszifikáció magában foglalja a cutan lymphoma típusokat is, lényegében egyezô módon a jelenleg érvényes 2005-ös WHO-EORTC cutan lymphoma beosztással $(18,19)$. A primer cutan diffúz nagy B-sej- tes lymphoma leg type (PCDLBCL-LT) a primer cutan Bsejtes lymphomák jól meghatározott csoportja, mely ritkább, mint a primer cutan folliculus centrum lymphoma (PCFCL) és a primer cutan marginális zóna lymphoma (PCMZL). A PCFCL-hez és a PCMZL-hez viszonyítva a PCDLBCL-LT prognózisa rosszabb, gyakoribb a disszeminált cutan és/vagy regionális érintettség, kezelésre szignifikánsan alacsonyabb a klinikai komplett válasz arány, gyakoribb a multiplex cutan relapsus és extracutan terjedés, rövidebb a teljes túlélés (OS) $(9,21)$.

A kis esetszámok miatt a statisztikai értékelésekben nagy a szórás. Az összes primer cutan lymphomák közt a PCDLBCL leg type gyakorisága 4\% (2-5\%), az 5 éves betegség specifikus túlélés 20-73\%. Idős kor és nôi dominancia jellemzi. A medián életkor nagyobb számú betegadat feldolgozása alapján PCDLBCL-LT esetén 70-79 év között, PCFCL és PCMZL esetén 50-66 év között változik $(9,18,21)$.

Klinikailag az egyik vagy mindkét alsó végtagon gyorsan növő, vörös vagy lividvörös papulák, plakkok, tumorok jellemzik, melyek ulcerálódhatnak. Lehet soliter, gyakrabban multiplex. A multiplex megjelenés rossz prognosztikai faktor (21). Ritkán nem alsó végtagi lokalizációban is kifejlődhet ez a lymphoma típus.

Szövettanilag ép epidermis alatt a dermist diffúzan beszûrô, nagyméretû, centroblast és immunoblast morfológiájú lymphoid sejtek helyezkednek el, gyakran a subcutisba is terjedve. Immunfenotípusa CD19+, CD20+, CD79a+, Bcl-2+, MUM-1+/-, Ig nehézlánc gén monoklonalitással. A Bcl-6 negativitás segíti elkülönítését a primer cutan folliculus centrum lymphomától, utóbbiban pozitív ez a reakció $(9,16)$.

Kezelése kis, soliter elváltozás esetén lehet sebészi vagy sugárkezelés, a rosszabb prognózisú, kiterjedtebb, több gócú cutan formákban és extracutan terjedés esetén immuno-kemoterápia (1, 3, 4, 20). A CHOP-kezelés az 1970-es évektôl a DLBCL-ek standard kezelésének számított. A molekuláris biológiai kutatások eredményei lehetôvé tették a biológiai célzott kezelések bevezetését, 1997-ben az FDA az anti-CD20 monoklonális antitestet, a rituximabot törzskönyvezte a follicularis lymphoma kezelésére. Azóta számos B-sejtes malignus haematológiai és autoimmun betegség terápiájában alkalmazzák. Sejtmediált citotoxicitás, antitestdependens cellularis citotoxicitás és apoptózis indukció révén CD20+ B-sejt pusztulást okoz. A 2000-es évek elején már bizonyítottá vált az RCHOP kezelés szignifikáns hatása a CHOP-hoz képest DLBCL-ben mind a teljes túlélésre, mind a progressziómentes túlélésre $(2,5,13,14,15,21)$. Ez a terápiás előny idős, 70 év feletti betegeknek a kemoterápiás szereket csökkentett adagban tartalmazó R-CHOP kezelésére is igazolt $(7,12)$, bár a vizsgálók egy része idős betegeknél így is gyakrabban észlelt súlyos mellékhatásokat (12). A nodális és extranodális formák CHOP és R-CHOP kezelésre adott válaszát értékelő tanulmány is igazolta az RCHOP előnyét minden formában, de a primer extranodális formák prognózisa rosszabb volt a rituximabbal kombinált esetekben is $(6,20)$. A rituximab okozta komplex 
immunológiai változások hatására a fertőzéssekkel szembeni védekezés csökkenhet. Az irodalmi adatok alapján rituximabbal kombinált kemoterápiák összehasonlítva a kemoterápiákkal, a fertózések rizikóját általában nem fokozzák (10,17). Rituximab kezelés során jelentôs veszély a hepatitis B vírus fertőzés reaktivációja, valamint hosszas alkalmazása növeli a fertőzés kockázatot autoimmun betegségekben, lymphomákban (17).

Napjainkban az R-CHOP már standard kezelésnek tekinthetô PCDLBCL alsó végtagi típusának multiplex gócú ill. disszeminálódó formáiban. Jelenleg egységes protokoll a másodvonalbeli kezelésre még nincs $(11,16,20)$.

Betegünk idős kora, társbetegségei, multiplex bőrtünete és emelkedett LDH szintje rossz prognózist jelzett. Ennek ellenére a csökkentett dózisú R-CHOP kezelést jól tolerálta, 2 hónapon belül remisszióba került, a kezelés kb. 5 hónapos jó életminőségú, tünetmentes időszakot eredményezett a bőrt, subcutist és izomzatot érintô, gyors progresszió előtt.

Köszönettel tartozunk $d r$. Pajor László professzornak (PTE ÁOK Pathológiai Intézet) a szövettani vizsgálatok elvégzéséért és a szövettani képek elkészítéséért.

\section{IRODALOM}

1. Brogan B. L., Zic J. A., Kinney M. C. és mtsai: Large B-cell lymphoma of the leg: clinical and pathologic characteristics in a North American series. J Am Acad Dermatol. (2003) 49(2), 223228.

2. Coiffier B., Lepage E., Briere J. és mtsai: CHOP chemotherapy plus rituximab compared with $\mathrm{CHOP}$ alone in elderly patients with diffuse large B-cell lymphoma. N Engl J Med (2002) 346, 235-242.

3. Dreno B.: Standard and new treatments in cutaneous B-cell lymphomas. J Cutan Pathol (2006) 33, 47-51.

4. Erốs N., Károlyi Zs.: A cutan B-sejtes lymphomákról 7 eset elemzése kapcsán. Bốrgyógy Vener Szle (2002) 1, 3-9.

5. Fields P. A., Linch D. C.: Treatment of the elderly patient with diffuse large B cell lymphoma. Br J Haematol. (2012) 157(2), 159-170

6. Gutiérrez-García G., Colomo L., Villamor N. és mtsai: Clinicobiological characterization and outcome of primary nodal and extranodal diffuse large B-cell lymphoma in the rituximab era. Leuk Lymphoma (2010) 51(7), 1225-1232.

7. Hasselblom S., Stenson M., Werlenius O. és mtsai: Improved outcome for very elderly patients with diffuse large B-cell lymphoma in the immunochemotherapy era. Leuk Lymphoma (2012) 53(3), 394-399.
8. Kim Y. H., Willemze R., Pimpinelli N. és mtsai: TNM classification system for primary cutaneous lymphomas other than mycosis fungoides and Sézary syndrome: a proposal of the International Society for Cutaneous Lymphomas (ISCL) and the Cutaneous Lymphoma Task Force of the European Organization of Research and Treatment of Cancer (EORTC). Blood (2007) 110, 479-484.

9. Kodama, K., Massone, C., Chott, A. és mtsai: Primary cutaneous large B-cell lymphomas: clinicopathologic features, classification, and prognostic factors in a large series of patients. Blood (2005) 106, 2491-2497.

10. Lanini S., Molloy A. C., Fine P. E. és mtsai: Risk of infection in patients with lymphoma receiving rituximab: systematic review and meta-analysis. BMC Med. (2011) 9, 36.

11. Leonard J. P., Martin P., Barrientos J. és mtsai: Targeted treatment and new agents in diffuse large B-cell lymphoma. Semin Hematol (2008) Jul;45(3 Suppl 2), 11-6.

12. Meguro A., Ozaki K., Sato K. és mtsai: Rituximab plus $70 \%$ cyclophosphamide, doxorubicin, vincristine and prednisone for Japanese patients with diffuse large B-cell lymphoma aged 70 years and older. Leuk Lymphoma (2012) 53(1), 43-49.

13. Nastoupil L. J., Rose A. C., Flowers C. R.: Diffuse large B-cell lymphoma: current treatment approaches. Oncology (Williston Park). (2012) 26(5), 488-495.

14. Pfreundschuh M.: How I treat elderly patients with diffuse large B-cell lymphoma. Blood (2010) 116(24), 5103-5110.

15. Schneider T., Molnár Zs., Deák B. és mtsai: Diffúz nagy B-sejtes lymphomák immunokemoterápiás kezelésével elért eredményeink. Orv Hetil (2009) 150(44), 2019-2026.

16. Senff N. J., Noordijk E. M., Kim Y.. H. és mtsai: European Organization for Research and Treatment of Cancer and International Society for Cutaneous Lymphoma consensus recommendations for the management of cutaneous B-cell lymphomas Blood (2008) 112, 1600-1609.

17. Simon Zs., Illés Á., Miltényi Zs. és mtsai: Immunológiai változások diffúz nagy B-sejtes lymphomában Rituximab-CHOP kezelést követôen: saját adatok elemzése és irodalmi áttekintés Orv Hetil (2012) 153(42), 1658-1666.

18. Willemze R., Jaffe E. S., Burg G. és mtsai: WHO-EORTC Classification for Cutaneous Lymphomas. Blood (2005) 105(10), 3768-3785.

19. Swerdlow S. H., Campo E., Harris N. L. és mtsai: WHO Classification of Tumours of Haemopoietic and Lymphoid Tissues. Lyon, IARC Press, 2008

20. Wobser M., Kneitz H., Bröcker E. B. és mtsai: Primary cutaneous diffuse large B-cell lymphoma, leg-type, treated with a modified R-CHOP immunochemotherapy - diagnostic and therapeutic challenges. J Dtsch Dermatol Ges (2011) 9(3), 204-211.

21. Zinzani, P. L., Quaglino, P., Pimpinelli, N. és mtsai: Prognostic Factors in Primery Cutaneous B-cell Lymphoma. J Clin Oncol (2006) 24, 1376-1382.

Érkezett: 2013. 04. 04.

Közlésre elfogadva: 2013. 06. 20.

A Bőrgyógyászati és Venerológiai Szemle Szerkesztősége fenntartja magának a jogot a hirdetések elfogadására, de a hirdetések tartalmáért nem vállal felelősséget. 